\title{
Stigma and Discrimination Against People Living with HIV and AIDS in Banyuwangi, East Java, Indonesia
}

\author{
Desak Made Sintha Kurnia Dewi ${ }^{1, *}$, Jayanti Dian Eka Sari², Mohammad Zainal \\ Fatah $^{3}$, Erni Astutik ${ }^{4}$
}

\begin{abstract}
${ }^{1}$ Research Group for Health and Well-being of Women and Children, Department of Biostatistics and Population Studies, Faculty of Public Health, Universitas Airlangga, Banyuwangi Campus, Banyuwangi, East Java, Indonesia

${ }^{2}$ Department of Health Promotion and Behavior Sciences, Faculty of Public Health, Universitas Airlangga, Banyuwangi Campus, Banyuwangi, East Java, Indonesia

${ }^{3}$ Research Group for Health and Well-being of Women and Children, Department of Health Promotion and Behavior Sciences, Faculty of Public Health, Universitas Airlangga, Surabaya, East Java, Indonesia

${ }^{4}$ Research Group for Health and Well-being of Women and Children, Department of Epidemiology, Faculty of Public Health, Universitas Airlangga, Surabaya, East Java Indonesia
\end{abstract}

*Corresponding author. Email: desaksintha@fkm.unair.ac.id

\begin{abstract}
Banyuwangi occupies the third highest position for HIV cases in East Java. Stigma and discrimination is one of the challenges in the success of controlling HIV and AIDS. Stigma increases the prevalence of HIV and AIDS and stops social and medical support to the patients. The study aim to explore stigma and discrimination experienced by PLWHA in Banyuwangi. This was a qualitative study conducted in Blambangan regional hospital in 2016 through in-depth interviews to 19 informants who selected purposively and recruited by health provider. The interview conducted for 60 minutes and recorded. Data was validated with triangulation techniques, analyzed using content analysis and presented in narrative. Stigma and discrimination mostly come from PLWHA itself. Factors that influence the occurrence of stigma are excessive fear of HIV, incomplete messages received by PLWHA and community caused the wrong and excessive perceptions arise, community values, norms and judgments. This stigma and discrimination is expressed in physical, social, verbal and institutional forms at the internal level of PLWHA and externally. Strengthening and empowerment through support group were needed to increase PLWHA confidence and involving PLWHA in HIV education to the community may decrease stigma and discrimination.
\end{abstract}

Keywords: stigma, discrimination, PLWHA, HIV and AIDS

\section{INTRODUCTION}

Globally, HIV and AIDS are the leading causes of death in people of reproductive age [1]. 37.9 million people globally were living with HIV [2]. Whereas, 1.7 million people became newly infected with HIV [2]. Every day around the world, nearly 7,000 people are infected with the HIV virus [3]. Whereas 36.2 million cases in adults and 1.7 million in children under 15 years old [2]. Tens of millions of people the following year were infected and living with HIV and AIDS, the number increasing in adults [4][5].

Indonesia, which is the Southeast Asian region, is one of the fastest growing HIV epidemics Since 2000 and has the fourth largest number of new HIV infections per year [6]. HIV prevalence has consistently been above $5 \%$ in several key populations where this has led Indonesia to concentrated epidemics pattern [7] and HIV prevalence is still low in the general population at $0.5 \%$ [6]. The number of AIDS-related deaths has increased by $60 \%$ since 2010 , from 24000 deaths to 38000 deaths [8].

Transmission of HIV and AIDS is dominated by heterosexual [9][11]. HIV and AIDS has also become health problem in Banyuwangi where the trend of HIV and AIDS cases has increased from year to year since 1999
[12]. Banyuwangi as the third highest for HIV cases in East Java [12]. HIV and AIDS case was founded almost in all areas of Banyuwangi. Meanwhile, there were about 3,800 HIV and AIDS cases in Banyuwangi. Ironically, they are housewives [13].

Various efforts have been made by local governments in overcoming this problem through the collaboration of various parties and formulating local regulations, but the problem of HIV and AIDS still occurs. Therefore, serious attention is needed in efforts to overcome them so as not to impact on a healthy society. One of the most important challenges for success in controlling HIV and AIDS transmission is stigma and discrimination [14][15]. Stigma and discrimination tend to isolate PLHA from the community and have a negative impact on their quality of life, cultivate negative self-image, fear and be judged negatively [14][16][17]

One of the most important challenges for success in controlling HIV and AIDS transmission is stigma and discrimination [18]. Stigma will increase the prevalence of HIV and AIDS and stop social and medical support because they have been labeled as PLWHA when they interact with their community [14][19]. 
Stigma and discrimination from the community tend to isolate ODHA and have a negative impact on their quality of life [14][16][17]. Although the prognosis of PLWHA can be improved with anti-retroviral treatment, they still have to face criticism and isolation from coworkers, family, health providers and the community because of their HIV status [20]. On the other hand, when PLWHA received love and attention by the community, they tend to take protective precautions in their sexual behavior and are more open about their HIV status to their partner [21][22]. Stigmatization can lead to actions and thoughts of prejudice among governments, the community, health service providers, employers, family members and colleagues [22]. There may be a number of health problems among HIV / AIDS patients, such as: loneliness, isolation, low self-esteem, identity crisis and lack of interest in HIV / AIDS prevention. These patients also lack motivation in practicing preventative measures, their behavior seeking care is low, and does not participate in routine HIV testing [14][16][17]. In a systematic review conducted by Bharat (2011), around one third to half of respondents including health care providers blamed PLWHA for bringing the disease to the community [23]. In terms of their role in community development, PLWHA are considered unable to contribute to their community [23]. In most situations, to prevent social rejection, PLWHA will not disclose their HIV status to avoid being isolated from participating in socio-cultural events [17]. Stigma will increase the prevalence of HIV / AIDS by stopping the provision of effective social and medical support [14][18][19] because PLWHA cannot interact with their families and communities which should make them feel complete, safe and become part of the community. Discrimination and exclusion from society is a consequence of the stigma that is usually experienced by PLWHA. As a result, HIV-infected patients choose not to disclose their HIV status and continue to engage in highrisk behavior. However, how HIV stigma affects PLWHA is not well understood, previous research has revealed that eliminating stigma in the population will increase individual and community acceptance of PLWHA. Understanding and overcoming obstacles to stigma and discrimination are important factors that need to be explored [17].

Blambangan Regional Hospital as a center for voluntary counseling and testing (VCT) and care support and treatment (CST) of PLWHA in Banyuwangi has a very large role. Most of PLWHAs in Banyuwangi and outside Banyuwangi accessed Anti Retro Viral (ARV) at Blambangan Hospital. Since its formation, almost $50 \%$ of HIV and AIDS cases in Banyuwangi have founded at Blambangan Hospital [12]. This makes Blambangan Hospital a strategic location to explore about stigma and discrimination against PLWHAs in Banyuwangi, East Java, Indonesia

\section{METHOD}

This research is a qualitative study using content analysis, which was conducted at Blambangan Regional Hospital in
August - October 2016. We interviewed 19 informants consisted of PLWHAs, families, health service providers and the community that selected purposively. The recruitment process of informants involved health provider who contacted with clients. Informants that involved in this research must be able to read, be able to communicate well, and be willing to be involved in this research.

Data collected through in-depth interviews with semistructured interview guidelines. Questions begin with open-ended questions such as activities, transmission experiences and challenges faced with their status, then explore to get deeper information related to stigma and discrimination. The interview process was carried out by the researchers themselves for 60 minutes per informant. The location and time of the interview are determined based on the informants' choice. Interview stopped until the data was saturated.

With the consent of the informant, the interview process was recorded using a voice recorder. To analyze data through several stages, starting with making transcripts then checking the completeness of the data, validated by triangulation techniques, then gathering information based on themes and making conclusions, data presented in narration. The ethical permit was approved and issued by the ethics committee of the Faculty of Public Health, Universitas Airlangga.

The socio-cognitive approach to understanding stigma is used as a theoretical foundation to see the interaction of individual perceptions with broader social processes, diseases related to stigma, strengths and stereotypes related to stigma will enable and strengthen one's stigmatization or acceptance.

\section{RESULTS AND DISCUSSION}

Majority of cases founded in Blambangan Hospital more than $50 \%$ of total cases in Banyuwangi. Based on data recorded at the VCT clinic at Blambangan Hospital, total number of case findings from 2005 - October 2016 was 975 clients consisted of $96.6 \%$ (942) adults and 3.4\% (33) children. While the number of people with HIV and AIDS who take anti-retroviral (ARV) treatment is $46.7 \%$ (455) clients. Of the risk factors, 323 of 942 clients (34.3\%) contracted through heterosexual relations, whether with permanent partners, irregular partners or clients of sex workers, 15 clients (1.6\%) because of occupational risks (female sex workers/CSWs), 50 clients $(5.3 \%)$ through homosexual relations, 44 people $(4.7 \%)$ due to injecting drugs user. the remaining $0.4 \%$ due to other factors including causes definitely unknown.

Total informants in this study were 19 people consisting of 11 PLWHAs, 3 families of PLWHA, 3 providers (advisors / case managers / program managers), and 2 general community. Most of the informants were graduated from high school education, and $68.4 \%$ work in private sector. Most PLWHAs have opened their status to their partner, and or families. Only 2 people were still keep it secret. However, most of the informants state that they keep their status secretly to the community/colleagues due to fear of 
being ostracized. Reasons for PLWHAs have not dared to open their status to spouse or family due to fear of gossip, being ostracized, being looked down on. In the other hand, informants who opened their HIV status to spouses or family because they wanted to get support and told by other family member because their spouse died because of HIV. Moreover, there was some informants who felt forced because their HIV status was opened by their family members without consent.

Based on interviews, most of the informants were infected through sexual intercourse with their regular or permanent partner. Some were transmitted through injecting drugs, and only a few proportion are transmitted through have same sex (man sex with man).

Informant have known HIV transmission through blood and body secretion through sexual intercourse, use unsterile needles together between drug users. They also have known how to prevent the transmission by using condoms and sterile needle. However, they were still fear of HIV through ordinary contact with PLWHA such as shaking hand, kissing on the cheeks, using same equipment, wear same clothes, and sleep in the same bed.

"... plates, used glass (PLWHA) are set apart, clothes, because I am afraid that I will be infected with HIV ...

If He/She drinks beer, the glass is also set aside so that He/She does not transmit ..." (Family of PLWHA)

"If I sleep in one room ... and one mattress I do not dare, I feel afraid. If the beds are separated, I.m okay, no problem "(Community)

This fear is not only conveyed by the community and families of PLWHA, but also by PLWHA themselves who have experienced and have provided information by health provider. It can trigger stigma and isolate PLWHA in all aspects of their lives. The relationship between HIV, morals and behavior are factors that contribute to the existence of HIV stigma such as behavior related to illegal actions, or sensitive matters in the community such as sex, prostitution, drug users.

There is a perception that HIV infection is the result of a person's life choices or individuals who choose bad / risky behavior is a mistake. A study in Zambia showed that immorality is the main factor that influenced the spread of HIV and AIDS, including stigma. Community thought, HIV infection had correlation with immoral behavior [24]. This must be clarified between an HIV infected person behaving who is considered immoral and someone who is actually an innocent victim. Most of the PLWHAs stated they were victims of their spouse and blamed as a bad person. Only a few of them admit their HIV status because of their own behavior.

HIV status have bring a huge impact on their life. They have to bear the heavy burden of declining health conditions and the stigma from their family and surrounding society without being able to do anything. The expressions and forms of stigma and discrimination that founded in this study divided into four groups including physical, social, verbal, and institutional stigma and discrimination. These groups can occur from and by internal PLWHA themselves and external such as spouses, families, colleagues, communities and health services.
Physical stigma and discrimination include isolation and violence. Physical isolation can occur in all locations both in homes, communities and public facilities. Expressions that usually appear at home such as gave a label, separated equipment or room. Expressions in public facilities such as did not sitting or getting too close to PLWHA. Other expressions are more extreme as manifestations of physical isolation such as being kicked out by family and divorced.

Social stigma and discrimination can be divided into social isolation, loss of identity and responsibility. Social alienation comes from various forms such as ignored and seemed to be forgotten by family and community. This was also experienced by several research informants

“... Why he is here?, if he knows that I'm sick (HIV) what I have to do?... Then, I noticed that he was taking the same medicine as me (ARV). The next visit I wear hijab, even though in my daily I don't wear the hijab" Informants had manipulated their appearance and identity so her HIV status is unknown by others (women, PLWHA)

Verbal stigma and discrimination can occur directly such as disputes, not being invited to communicate, pressure, be judged, etc. And indirect things like rumors or rumors in the family or community.

"... I live in my husband's house and the location is close to my husband's families. Many of the innuendo that I received were said to have a sister who was ill (HIV). Surely her husband was also infected with HIV. I was not strong with the insinuation and left home now I am renting a house "- persecuted through sarcasm about her HIV status (Woman, PLWHA)

Stigma and institutional discrimination refer to differences in care with others members such as being unable to carry out life, household needs, health care, losing access to opportunities for new opportunities such as work, travel, education.

"... The obstacle if doing treatment for B20 (HIV) patients is to be treated last, both outpatients in poly who require treatment are treated lastly. Sometimes there are still staff who say they have B20 (HIV), served last "(woman, Health Provider)

"... This child is HIV, the severity of discrimination is not only from the family of this child but also the surrounding community. If this child is at school sitting at the back. There is even a guardian of students from the school said her daughter will be transferred to another school if this HIV child continues to attend school here "(woman, AIDS commission)

The government has tried to reduce stigma and discrimination in society but so far the problem still remains. So far, many people think that stigma and discrimination only come from the community. But in this study founded the most stigma and discrimination comes from PLWHA itself and outside of PLWHA such as health services, work environment, household and community. Self-stigma / internal stigma is a form of evaluation carried out by PLWHA and can adversely affect the mentality of PLWHA. Their own fears of negative reaction from others can reduce efforts to prevent HIV and AIDS because it 
will be a hidden barrier that is difficult to solve. A summary of the findings in this study can be seen in Table 1. The stigma and discrimination experienced by PLWHA in Banyuwangi is not only from outside individuals such as families, communities and services. Stigma and Discrimination are actually mostly by PLWHA themselves. It was caused by knowledge and fear of HIV, the values, norms and moral judgment of PLWHA. This research was in line with studies conducted in Thailand of nursing graduates and nursing professionals that infections experienced by PLWHAs were associated with immoral behavior and as an immoral group [25]

Expressions and forms of stigma and discrimination against HIV are divided into physical, social, verbal and institutional stigma and discrimination. Where the four stigma and discrimination groups can be done internally with PLWHA and from outside.

Table 1. PLWHA Stigma and Discrimination

\begin{tabular}{|c|c|c|c|c|c|c|c|}
\hline \multicolumn{8}{|c|}{ Stigma to PLWHA } \\
\hline \multicolumn{2}{|c|}{ Physic } & \multicolumn{2}{|c|}{ Social } & \multicolumn{2}{|c|}{ Verbal } & \multicolumn{2}{|c|}{ Institutional } \\
\hline Self-stigma & $\begin{array}{c}\text { External- } \\
\text { stigma }\end{array}$ & $\begin{array}{l}\text { Self- } \\
\text { stigma }\end{array}$ & $\begin{array}{l}\text { External- } \\
\text { stigma }\end{array}$ & $\begin{array}{c}\text { Self- } \\
\text { stigma }\end{array}$ & $\begin{array}{c}\text { External- } \\
\text { stigma }\end{array}$ & $\begin{array}{c}\text { Self- } \\
\text { stigma }\end{array}$ & $\begin{array}{c}\text { External- } \\
\text { stigma }\end{array}$ \\
\hline isolation & isolation & isolation & isolation & labelling & gossiping & & \\
\hline $\begin{array}{c}\text { afraid to } \\
\text { shake hands }\end{array}$ & $\begin{array}{l}\text { It is } \\
\text { recommended } \\
\text { not to use } \\
\text { shared toilets }\end{array}$ & $\begin{array}{l}\text { shut } \\
\text { yourself } \\
\text { out of } \\
\text { relationshi } \\
\text { ps }\end{array}$ & $\begin{array}{l}\text { not } \\
\text { considered } \\
\text { by the family }\end{array}$ & $\begin{array}{l}\text { Labellin } \\
\mathrm{g} \text { her/his } \\
\text { self } \\
\text { dirty, } \\
\text { badly, } \\
\text { do not } \\
\text { deserve } \\
\text { to live }\end{array}$ & $\begin{array}{l}\text { neighbor's } \\
\text { satire about } \\
\text { her HIV } \\
\text { status }\end{array}$ & $\begin{array}{l}\text { travel is } \\
\text { difficult } \\
\text { because it } \\
\text { depends on } \\
\text { ARV } \\
\text { services }\end{array}$ & $\begin{array}{l}\text { judgment } \\
\text { if IDU } \\
\text { means } \\
\text { AIDS }\end{array}$ \\
\hline $\begin{array}{l}\text { afraid to kiss } \\
\text { their own } \\
\text { child }\end{array}$ & $\begin{array}{l}\text { it is } \\
\text { recommended } \\
\text { to separate } \\
\text { the toiletries } \\
\text { from other } \\
\text { family } \\
\text { members }\end{array}$ & $\begin{array}{l}\text { don't dare } \\
\text { to remarry } \\
\text { and start a } \\
\text { relationshi } \\
\text { p }\end{array}$ & $\begin{array}{l}\text { Skin } \\
\text { problems is } \\
\text { considered } \\
\text { HIV }\end{array}$ & & $\begin{array}{l}\text { my husband } \\
\text { kept talking } \\
\text { about the } \\
\text { pain caused } \\
\text { by HIV }\end{array}$ & & \\
\hline $\begin{array}{l}\text { afraid of } \\
\text { receiving food } \\
\text { from others }\end{array}$ & & $\begin{array}{l}\text { don't dare } \\
\text { to have } \\
\text { children }\end{array}$ & & & get insulted & & \\
\hline $\begin{array}{l}\text { want to end } \\
\text { life }\end{array}$ & & $\begin{array}{l}\text { don't dare } \\
\text { to be } \\
\text { involved } \\
\text { in cooking } \\
\text { in the } \\
\text { kitchen }\end{array}$ & & & $\begin{array}{l}\text { judgment for } \\
\text { HIV } \\
\text { volunteers } \\
\text { who are } \\
\text { considered } \\
\text { PLWHA }\end{array}$ & & \\
\hline & & & & & $\begin{array}{l}\text { pressured to } \\
\text { break } \\
\text { relationship } \\
\text { with her } \\
\text { boyfriend } \\
\end{array}$ & & \\
\hline & & & & & $\begin{array}{l}\text { laughed at } \\
\text { his fellow } \\
\text { PLWHA } \\
\text { because his } \\
\text { illness got } \\
\text { worse }\end{array}$ & & \\
\hline
\end{tabular}


Discrimination to PLWHA

\begin{tabular}{|c|c|c|c|c|c|c|c|}
\hline \multicolumn{2}{|c|}{ Physic } & \multicolumn{2}{|c|}{ Social } & \multicolumn{2}{|c|}{ Verbal } & \multicolumn{2}{|c|}{ Institutional } \\
\hline Self-stigma & $\begin{array}{c}\text { External- } \\
\text { stigma }\end{array}$ & $\begin{array}{l}\text { Self- } \\
\text { stigma }\end{array}$ & $\begin{array}{c}\text { External- } \\
\text { stigma }\end{array}$ & $\begin{array}{c}\text { Self- } \\
\text { stigma }\end{array}$ & $\begin{array}{c}\text { External- } \\
\text { stigma }\end{array}$ & $\begin{array}{l}\text { Self- } \\
\text { stigma }\end{array}$ & $\begin{array}{c}\text { External- } \\
\text { stigma }\end{array}$ \\
\hline isolation & isolation & isolation & isolation & & & & \\
\hline $\begin{array}{c}\text { Separate } \\
\text { utensils by } \\
\text { her/his self }\end{array}$ & $\begin{array}{l}\text { Separate } \\
\text { utensils by } \\
\text { family } \\
\text { member }\end{array}$ & $\begin{array}{l}\text { Avoid } \\
\text { visiting } \\
\text { family }\end{array}$ & $\begin{array}{l}\text { Husband } \\
\text { avoid and } \\
\text { often back } \\
\text { home late }\end{array}$ & & $\begin{array}{l}\text { husband } \\
\text { does not } \\
\text { want to } \\
\text { communicat } \\
\text { e }\end{array}$ & & $\begin{array}{c}\text { work } \\
\text { terminatio } \\
n\end{array}$ \\
\hline $\begin{array}{l}\text { Does not want } \\
\text { to drink from } \\
\text { same glass }\end{array}$ & $\begin{array}{c}\text { separate } \\
\text { laundry } \\
\text { basket }\end{array}$ & $\begin{array}{c}\text { lock } \\
\text { yourself in } \\
\text { the house, } \\
\text { do not } \\
\text { want to } \\
\text { gather } \\
\text { with } \\
\text { residents }\end{array}$ & $\begin{array}{l}\text { husband } \\
\text { refuses to } \\
\text { sexual } \\
\text { intercourse }\end{array}$ & & $\begin{array}{c}\text { husband } \\
\text { continues to } \\
\text { bring up the } \\
\text { problem of } \\
\text { HIV disease } \\
\text { from } \\
\text { PLWHA }\end{array}$ & & $\begin{array}{l}\text { rooms in } \\
\text { the church } \\
\text { are } \\
\text { separated }\end{array}$ \\
\hline \multirow[t]{4}{*}{$\begin{array}{l}\text { not let other } \\
\text { people wear } \\
\text { their clothes }\end{array}$} & $\begin{array}{l}\text { Refuse to } \\
\text { sexual } \\
\text { intercourse }\end{array}$ & $\begin{array}{l}\text { limit their } \\
\text { children } \\
\text { activities }\end{array}$ & $\begin{array}{l}\text { husband is } \\
\text { looking for } \\
\text { another } \\
\text { woman }\end{array}$ & & $\begin{array}{l}\text { HIV status is } \\
\text { spread by } \\
\text { family } \\
\text { members }\end{array}$ & & $\begin{array}{c}\text { lost school } \\
\text { opportunit } \\
y\end{array}$ \\
\hline & $\begin{array}{l}\text { the family } \\
\text { refused the } \\
\text { food is given } \\
\text { by PLWHA }\end{array}$ & $\begin{array}{l}\text { just want } \\
\text { to have a } \\
\text { relationshi } \\
\text { p with } \\
\text { PLWHA }\end{array}$ & $\begin{array}{l}\text { refused the } \\
\text { food is given } \\
\text { by PLWHA }\end{array}$ & & $\begin{array}{l}\text { HIV status is } \\
\text { spread by } \\
\text { other } \\
\text { PLWHA }\end{array}$ & & $\begin{array}{l}\text { separate } \\
\text { desks and } \\
\text { chairs in } \\
\text { school }\end{array}$ \\
\hline & $\begin{array}{l}\text { re-washing } \\
\text { utensils that } \\
\text { have been } \\
\text { washed by } \\
\text { PLWHA }\end{array}$ & $\begin{array}{c}\text { Lost } \\
\text { identity or } \\
\text { role }\end{array}$ & $\begin{array}{l}\text { don't want to } \\
\text { say hello to } \\
\text { PLWHA }\end{array}$ & & & & $\begin{array}{c}\text { medical } \\
\text { treatment } \\
\text { at the latest }\end{array}$ \\
\hline & Violence & $\begin{array}{c}\text { Lost } \\
\text { power for } \\
\text { decision } \\
\text { making }\end{array}$ & $\begin{array}{l}\text { refused to } \\
\text { attend the } \\
\text { PLWHA } \\
\text { funeral }\end{array}$ & & & & $\begin{array}{c}\text { HIV } \\
\text { testing } \\
\text { without } \\
\text { notifying } \\
\text { the client }\end{array}$ \\
\hline
\end{tabular}

Activities that carried out to reduce stigma and discrimination in the community and especially in PLWHA themselves are needed such as 1) Strengthening and empowering PLWHA: about the rights they have through socialization, increasing independence through increasing soft and hard skills by providing training to improve the economy, increase self-confidence, quality of life and health through training in the management of diseases for PLHIV in the home environment, forming support groups as a place of discussion for the convenience of the practice of PLWHA for self-acceptance. 2) Reduce stigma in the Community through HIV and AIDS Education continuously to make community catch the complete message and have the same perception. 3) Involving PLWHA in the education process to the community, so 
they are accustomed to interacting and fostering selfconfidence. 4) Service coordination and strengthening of HIV and AIDS networks.

\section{CONCLUSION}

Stigma and discrimination against HIV and AIDS still occur in Banyuwangi. The stigma and discrimination experienced by PLWHA in Banyuwangi is not only from outside such as family, community and services but also from PLWHA itself. The causes of stigma and discrimination were the lack of awareness, fear of HIV, the values, norms and moral judgment of PLWHA. Expressions and forms of stigma and discrimination against HIV are as follows, physical, social, verbal and institutional stigma and discrimination. Where the four stigma and discrimination groups can be done internally with PLWHA and from outside. Strengthening and empowering through support groups is needed to increase the trust of PLWHA and involve PLWHA in HIV education. Coordination and strengthening of HIV and AIDS networks were needed to reduce stigma and discrimination.

\section{REFERENCES}

[1] World Health Organization Women's Health. 2009.

[2] UNAIDS Global HIV \& AIDS statistics - 2019 fact sheet. 2019.

[3] Piot, P., et al., Coming to Terms with Complexity: a Call to Action for HIV Prevention The Lancet, 2008. 372(9641): p. 845-859

[4] Avert HIV and AIDS in Asia. 2011.

[5] National AIDS Commission Republic of Indonesia, Republic of Indonesia, Country Report on the Follow up to the Declaration of Commitment On HIVIAIDS (UNGASS), Reporting Period 2008 - 2009. 2009, National AIDS Commission Republic of Indonesia: Jakarta.

[6] Cairns, G. Indonesia: tackling HIV in one of the world's fastest-growing epidemics. 2018.

[7] Komisi Penanggulangan AIDS Nasional, Strategi Nasional Penanggulangan HIV dan AIDS 2007-2010. 2007, Komisi Penanggulangan AIDS Nasional: Jakarta.

[8] UNAIDS Country Indonesia. 2018.

[9] Kurnia Dewi, D.M.S., L. Wulandari, and N. Mangku Karmaya, Women's vulnerability to STIs and HIV transmission: high risk sexual behaviour in Denpasar City. Public Health and Preventive Medicine Archive, 2013. 1(1).

[10] Dewi, D.M.S.K., L.P.L. Wulandari, and D.N. Wirawan, DETERMINAN SOSIAL KERENTANAN PEREMPUAN TERHADAP PENULARAN IMS DAN HIV. Journal of Public Health Research and Community Health Development, 2018. 2(2): p. 22-35.
[11] Komisi Penanggulangan AIDS Nasional, Strategi dan Rencana Aksi Nasional Penanggulangan HIV dan AIDS 2010-2014. 2010, Komisi Penanggulangan AIDS Nasional: Jakarta.

[12] Dinas Kesehatan Kabupaten Banyuwangi, Profil Kesehatan Kabupaten Banyuwangi Tahun 2014. 2014, Pemerintah Kabupaten Banyuwangi: Banyuwangi.

[13] Pemerintah Kabupaten Banyuwangi Wabup Yusuf Resmikan Gedung Penanggulangan HIV/AIDS. 2019.

[14] Tran, B.X., et al., Understanding Global HIV Stigma and Discrimination: Are Contextual Factors Sufficiently Studied? (GAP(RESEARCH)). International journal of environmental research and public health, 2019. 16(11): p. 1899.

[15] Feyissa, G.T., et al., Stigma and discrimination against people living with HIV by healthcare providers, Southwest Ethiopia. BMC Public Health, 2012. 12(1): p. 522.

[16] Centers for Disease Control and Prevention (CDC) Facts about HIV Stigma. 2019.

[17] Dahlui, M., et al., HIV/AIDS Related Stigma and Discrimination against PLWHA in Nigerian Population. PLoS One, 2015. 10(12).

[18] Avert HIV STIGMA AND DISCRIMINATION. 2019.

[19] Stringer, K.L., et al., HIV-Related Stigma Among Healthcare Providers in the Deep South. AIDS and behavior, 2016. 20(1): p. 115-125.

[20] UNAIDS UNAIDS warns that HIV-related stigma and discrimination is preventing people from accessing HIV services. 2017.

[21] Klinik VCT RSUD Blambangan, Sistem Informasi HIV dan AIDS. 2016, RSUD Blambangan: Banyuwangi.

[22] C Rongkavilit, et al., HIV stigma, disclosure and psychosocial distress among Thai youth living with HIV. International Journal of STD and AIDS, 2010. 21(2).

[23] Bharat, S., A Systematic Review of HIV/AIDSRelated Stigma and Discrimination in India: Current Understanding and Future Needs. SAHARA-J: Journal of Social Aspects of HIV/AIDS, 2011: p. 138-149.

[24] Bond, V., E. Chase, and P. Aggleton, Stigma, HIV/AIDS and prevention of mother-to-child transmission in Zambia. Evaluation and Program Planning, 2002. 25(4): p. 347-356.

[25] Sian Churcher,Stigma Related to HIV and AIDS as a Barrier to Accessing Health Care in Thailand: a Review of Recent Literature WHO South-East Asia Journal of Public Health, 2013. 2(1): p. 12-22. 